\title{
Therapeutic potential of the cannabinoid receptor 2 in neuropsychiatry
}

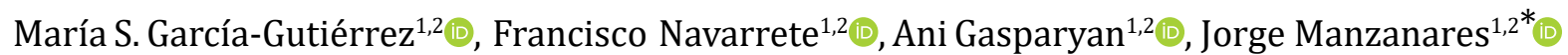 \\ ${ }^{1}$ Instituto de Neurociencias, Universidad Miguel Hernández-CSIC, Avda de Ramón y Cajal s/n, San Juan de Alicante, 03550 \\ Alicante, Spain \\ ${ }^{2}$ Red Temática de Investigación Cooperativa en Salud (RETICS), Red de Trastornos Adictivos, Instituto de Salud Carlos III, \\ MICINN and FEDER, 28029 Madrid, Spain
}

*Correspondence: Jorge Manzanares, Instituto de Neurociencias, Universidad Miguel Hernández-CSIC, Avda de Ramón y Cajal s/n, San Juan de Alicante, 03550 Alicante, Spain. jmanzanares@goumh.umh.es

Academic Editor: Rafael Franco, Universidad de Barcelona, Spain

Received: March 27, 2021 Accepted: May 6, 2021 Published: August 5, 2021

Cite this article: García-Gutiérrez MS, Navarrete F, Gasparyan A, Manzanares J. Therapeutic potential of the cannabinoid receptor 2 in neuropsychiatry. Explor Neuroprot Ther. 2021;1:55-71. https://doi.org/10.37349/ent.2021.00006

\begin{abstract}
Since the identification and cloning of the cannabinoid receptor $2\left(\mathrm{CB}_{2} \mathrm{R}\right)$, several studies focused on the characterization of its physiological and pathological role. Initially, $\mathrm{CB}_{2} \mathrm{R}$ was considered as the peripheral cannabinoid receptor due to its detection in the rat spleen and leukocyte subpopulation in humans. Later, $\mathrm{CB}_{2} \mathrm{R}$ was identified in different brain regions significantly modifying the landscape and pointing out its role in a wide variety of central physiological functions and pathological conditions. Additional research also detected the expression of $\mathrm{CB}_{2} \mathrm{R}$ in neurons, microglia, and astroglia in different brain regions. Indeed, the findings collected to date support a significant function of $\mathrm{CB}_{2} \mathrm{R}$ in anxiety, depression, schizophrenia, and additional neuropsychiatric disorders. This review gathers the most relevant literature regarding new advances about the role of $\mathrm{CB}_{2} \mathrm{R}$ in a variety of neuropsychiatric conditions, with special emphasis on its potential as a new therapeutic target for the treatment of different psychiatric disorders.
\end{abstract}

\section{Keywords}

Cannabinoid receptor 2, psychiatry, emotional response, anxiety, depression, schizophrenia, bipolar disorder

\section{Introduction}

The cannabinoid receptor $2\left(\mathrm{CB}_{2} \mathrm{R}\right)$ along with the cannabinoid receptor $1\left(\mathrm{CB}_{1} \mathrm{R}\right)$ are the receptors of the endogenous cannabinoid system (ECS). Early research focused on elucidating the physiological role and therapeutic utility of $\mathrm{CB}_{1} \mathrm{R}$ in neuropsychiatry since it was the first cannabinoid receptor identified in the central nervous system (CNS). However, the detection of $\mathrm{CB}_{2} \mathrm{R}$ in neurons and glia in different brain regions has increased the number of investigations to elucidate its role at the central level, beyond its initial consideration as a "peripheral cannabinoid receptor". This review summarizes the main findings highlighting the involvement of $\mathrm{CB}_{2} \mathrm{R}$ in different physiological processes such as stress response, emotional reactivity, and cognitive processing that are affected in different psychiatric disorders (anxiety, depression, schizophrenia, 
and bipolar disorder), as well as the evidence supporting its therapeutic potential in the pharmacological approach to these pathologies.

\section{Characterization of the ECS}

ECS components are endogenous ligands, including anandamide (AEA) [1] and 2-arachidonoyl glycerol (2AG) $[2,3]$, synthesis enzymes, such as $N$-acylphosphatidylethanolamine phospholipase D (NAPE-PLD) and diacylglycerol lipase (DAGL), metabolizing enzymes, such as fatty acid amide hydrolase (FAAH) [4, 5] and monoacylglycerol lipase (MAGL) [6-9], and cannabinoid receptors $\mathrm{CB}_{1} \mathrm{R}$ [10], $\mathrm{CB}_{2} \mathrm{R}$ [11] and, more recently, G protein-coupled receptor 55 (GPR55) $[12,13]$, known as non- $\mathrm{CB}_{1}$ non- $\mathrm{CB}_{2}$ cannabinoid-related receptor (Figure 1). Besides, cannabinoids act on transient receptor potential (TRP) channels, particularly on TRP vanilloid 1 (TRPV1), causing these receptors to be called ionotropic cannabinoid receptors [14, 15].

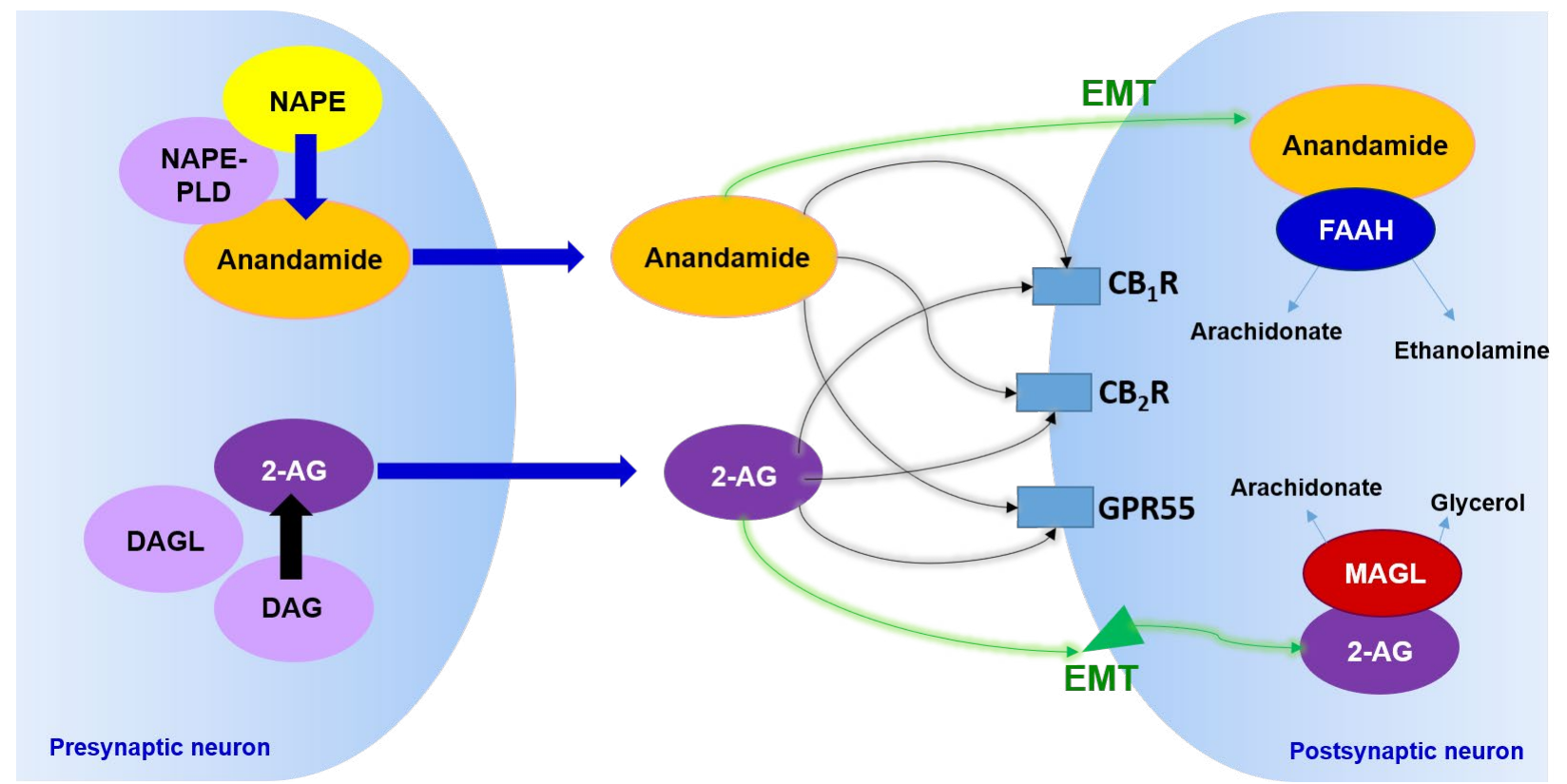

Figure 1. Characterization of the ECS. The image represents schematically the main elements of the ECS described to date. NAPE: $N$-acylphosphatidylethanolamine; DAG: diacylglycerol; EMT: endocannabinoid membrane transporter

Contrary to most neurotransmitters, endogenous cannabinoids are not stored in synaptic vesicles but are synthesized and released on demand by postsynaptic neurons and accompanying glial cells in response to changes in neuronal activity [16-18]. Once released, they act on specific cannabinoid receptors, predominantly $\mathrm{CB}_{1} \mathrm{R}$ and $\mathrm{CB}_{2} \mathrm{R}$.

$\mathrm{CB}_{1} \mathrm{R}$ is widely distributed in the brain (cingulate cortex, entorhinal cortex, caudate nucleus and putamen, hippocampus, amygdala, thalamus, substantia nigra, medial hypothalamus, globus pallidus, nucleus tractus solitarius, cerebellum, and substantia gelatinosa of the spinal cord) $[10,19,20]$. This receptor has been proposed as a therapeutic target in the treatment of chemotherapy-associated nausea and vomiting [21, 22], in the treatment of anorexia in patients with acquired immunodeficiency syndrome [23, 24], chronic pain [25], spastic pain in multiple sclerosis [26], psychosis [27] and in anxiety disorders and depression [28-30].

The first attempts to identify the expression of $\mathrm{CB}_{2} \mathrm{R}$ in the brain under normal conditions resulted unsuccessful [31-35]. In 2005, Van Sickle et al. [36], published the first information identifying the neuronal expression of $\mathrm{CB}_{2} \mathrm{R}$ in the brainstem of rats, mice, and ferret under physiological conditions. These results served as a precedent for the full characterization of $\mathrm{CB}_{2} \mathrm{R}$ expression in rat and mouse brains years later [37-39].

The wide distribution of $\mathrm{CB}_{2} \mathrm{R}$, both in neurons and glia, in various brain areas (striatum, cerebral cortex, amygdala, hippocampus, substantia nigra, olfactory tubercle, thalamic nuclei, ventromedial nucleus of the hypothalamus, paralemniscal nucleus, pontine nuclei, red nucleus, inferior colliculus, spinal nucleus, paratrochlear nucleus, and cerebellum), ended the idea that $\mathrm{CB}_{2} \mathrm{R}$ presents an exclusively peripheral 
role, opening news avenues to research on its potential involvement in different brain functions and neuropsychiatric disorders [37, 39-44].

\section{Involvement of $\mathrm{CB}_{2} \mathrm{R}$ in anxiety-related disorders}

The presence of $\mathrm{CB}_{2} \mathrm{R}$ in brain areas closely related to the response to stress and anxiety, such as the hippocampus and the amygdala, has led to the study of its possible involvement in these conditions [37, 39]. One of the main tools to evaluate the involvement of this receptor in anxiety has been the development of animal models that allow us to assess the response of rodents to anxiogenic stimuli. These models have been employed to evaluate whether genetic or pharmacological manipulation of $\mathrm{CB}_{2} \mathrm{R}$ modifies the response to anxiogenic stimuli in different experimental paradigms.

Interestingly, our group showed that transgenic mice overexpressing $\mathrm{CB}_{2} \mathrm{R}$ in the $\mathrm{CNS}\left(\mathrm{CB}_{2} \mathrm{xP}\right.$ mice$)$ present a resistant phenotype against anxiogenic stimuli in the light-dark box and the elevated plusmaze [43]. Complementarily, mice lacking the $\mathrm{CB}_{2} R$ gene $\left(\mathrm{CB}_{2}^{-\%}\right.$ mice $)$ develop higher levels of anxiety in both behavioral tests [44].

Another approach to study the role of $\mathrm{CB}_{2} \mathrm{R}$ in anxiety has been to evaluate the effects of intracerebroventricular (icv) administration of an antisense probe designed against $\mathrm{CB}_{2} \mathrm{R}$ messenger RNA in rodents [45]. In this study, the authors demonstrated that the blockade of the $C B_{2} R$ gene is associated with a reduction in anxiety-like behaviors, in contrast to the results obtained with genetically modified mice. These discrepancies could be related to the antisense probe administered icv, which may affect different brain regions and in a different manner (more acutely) in comparison with the genetic deletion, in addition to the distinct genetic background of the strains of mice used in these studies [DBA/2, C57BL/6], BALB/c, and institute of cancer research (ICR)] (Table 1).

The effects of the pharmacological modulation of $\mathrm{CB}_{2} \mathrm{R}$ by agonists and antagonists were also evaluated. Acute administration of the $\mathrm{CB}_{2}$ R agonists GW405833 (100 mg/kg) and JWH015 (1-20 mg/kg) show anxiolytic effects on the rotarod [46] and the elevated plus-maze [38], respectively. However, depending on the agonist, the dose used, and the test employed, some authors find no differences [46, 47] or, on the contrary, anxiogenic effects are observed [45]. These discrepancies show that the effects would be influenced by several factors such as 1) the drug used, 2) the route and pattern of administration (acute vs. chronic) evaluated, 3) the behavioral test, and 4) the species and animal strains studied (rat, mouse; Table 1).

The effects induced by the blockade of $\mathrm{CB}_{2} \mathrm{R}$ by antagonists, such as that produced by compound AM630, were also evaluated. Its acute administration $(1,2$, or $3 \mathrm{mg} / \mathrm{kg})$ in ICR mice induces anxiogenic effects in the LDB. Interestingly, these effects are not found in the previous administration of a $\mathrm{CB}_{2} \mathrm{R}$ agonist (JWH133), supporting the involvement of $\mathrm{CB}_{2} \mathrm{R}$ in anxiety [47]. The change of the administration pattern from acute to chronic also modifies the effects mediated by $\mathrm{CB}_{2} \mathrm{R}$ agonist or antagonist compounds. Indeed, chronic administration of the antagonist $\operatorname{AM} 630(1,2$, or $3 \mathrm{mg} / \mathrm{kg})$ exhibits anxiolytic effects in the light-dark box and the EPMs, while the agonist JWH133 $(0.5,1$, or $2 \mathrm{mg} / \mathrm{kg})$ presents anxiogenic actions. These effects are accompanied by increased $C B_{2} R$ gene expression in the amygdala and cortex, key regions involved in emotional response, in AM630-treated mice. Moreover, chronic activation of $\mathrm{CB}_{2} \mathrm{R}$ by the agonist JWH133 reduced $C B_{2} R$ gene expression in both regions [47]. These findings agree with the results found in studies performed with genetically modified mice, in which $\mathrm{CB}_{2} \mathrm{R}$ overexpression is associated with resistance to developing anxietylike behaviors [43] and, on the contrary, its absence is associated with greater vulnerability [44].

In animal models of social defeat, paradigms of psychosocial anxiety, a reduction of $C B_{2} R$ gene expression was found in different regions of the hippocampus [cornu ammonis-1 (CA1) and dentate gyrus] both in mice that develop submissive behavior towards the aggressor and in those that develop avoidance behavior [48]. Additionally, it has been noted that the absence of $\mathrm{CB}_{2} \mathrm{R}$ produces increased aggressiveness in the social interaction test and the social defeat model [49]. In this same study, the acute administration of the agonist JWH133 (1, 2, or $4 \mathrm{mg} / \mathrm{kg}$ ) reduces the aggressive behavior of wild-type mice exposed to this model. Taken together, these results support the involvement of the $\mathrm{CB}_{2} \mathrm{R}$ in the regulation of adaptive responses to environmental factors. 
Table 1. Major findings supporting the involvement of $\mathrm{CB}_{2} \mathrm{R}$ in anxiety disorders

\begin{tabular}{|c|c|c|c|c|c|c|c|}
\hline \multicolumn{8}{|c|}{ Animal studies } \\
\hline \multirow[t]{6}{*}{$\begin{array}{l}\text { Genetic } \\
\text { studies }\end{array}$} & $\begin{array}{l}\text { Genetic } \\
\text { manipulation }\end{array}$ & \multicolumn{2}{|l|}{ Animal specie } & $\begin{array}{l}\text { Experimental } \\
\text { test }\end{array}$ & \multicolumn{2}{|c|}{ Behavioral changes } & References \\
\hline & \multirow[t]{2}{*}{$\mathrm{CB}_{2} \mathrm{xP}$} & \multirow{2}{*}{\multicolumn{2}{|c|}{ Mouse, ICR }} & LDB & \multicolumn{2}{|l|}{$\downarrow$ vulnerability } & [39] \\
\hline & & & & EPM & \multicolumn{2}{|c|}{$\begin{array}{l}\text { ( } \downarrow \text { time in the lighted box and } \\
\text { open arms) }\end{array}$} & \\
\hline & \multirow{2}{*}{$\mathrm{CB}_{2}^{-1-}$} & \multirow{2}{*}{\multicolumn{2}{|c|}{ Mouse, ICR }} & LDB & \multirow{2}{*}{\multicolumn{2}{|c|}{$\begin{array}{l}\uparrow \text { vulnerability } \\
\text { ( } \uparrow \text { time in the lighted box and } \\
\text { open arms) }\end{array}$}} & {$[44]$} \\
\hline & & & & EPM & & & \\
\hline & Cnr2 KO & \multicolumn{2}{|c|}{ Mouse, C57BL/6J } & SD & \multicolumn{2}{|c|}{$\uparrow$ aggressive behavior } & [49] \\
\hline \multirow{13}{*}{$\begin{array}{l}\text { Pharma- } \\
\text { cological } \\
\text { studies }\end{array}$} & \multirow[t]{8}{*}{$\begin{array}{l}\text { Acute } \\
\text { treatment }\end{array}$} & Drug & Animal specie & $\begin{array}{l}\text { Experimental } \\
\text { test }\end{array}$ & Dosis & $\begin{array}{l}\text { Behavioral } \\
\text { changes }\end{array}$ & References \\
\hline & & $\begin{array}{l}\mathrm{CB}_{2} \mathrm{R} \\
\text { messenger } \\
\text { RNA antisense } \\
\text { probe }\end{array}$ & $\begin{array}{l}\text { Mouse, DBA/2, } \\
\text { C57BL/6J, BALB/c }\end{array}$ & EPM & $\begin{array}{l}4 \mu \mathrm{g} / \mu \mathrm{L} \text { per } 12 \\
\mathrm{~h}(3 \text { days })\end{array}$ & $\begin{array}{l}\downarrow \text { anxiogenic } \\
\text { response }\end{array}$ & {$[45]$} \\
\hline & & $\begin{array}{l}\text { JWH015 } \\
\text { (CB } 2 \text { R agonist) }\end{array}$ & $\begin{array}{l}\text { Mouse, DBA/2, } \\
\text { C57BL/6J, BALB/c }\end{array}$ & EPM & $1-20 \mathrm{mg} / \mathrm{kg}$ & $\begin{array}{l}\uparrow \text { anxiogenic } \\
\text { response }\end{array}$ & [38] \\
\hline & & \multirow{2}{*}{$\begin{array}{l}\text { JWH133 } \\
\text { (CB }{ }_{2} \mathrm{R} \text { agonist) }\end{array}$} & Mouse, ICR & LDB, EPM & $0.5,1,2 \mathrm{mg} / \mathrm{kg}$ & No effect & {$[47]$} \\
\hline & & & Mouse, C57BL/6J & SD & $1,2 \mathrm{mg} / \mathrm{kg}$ & $\begin{array}{l}\downarrow \text { aggressive } \\
\text { behavior }\end{array}$ & [49] \\
\hline & & \multirow[t]{2}{*}{$\begin{array}{l}\text { GW405833 } \\
\left.\text { (CB }{ }_{2} R \text { agonist }\right)\end{array}$} & Mouse, C57BL/6J & MB & $\begin{array}{l}10,30,100 \\
\mathrm{mg} / \mathrm{kg}\end{array}$ & $\begin{array}{l}\downarrow \text { anxiogenic } \\
\text { response }\end{array}$ & [46] \\
\hline & & & Rat, Sprague-Dawley & Rotarod & $100 \mathrm{mg} / \mathrm{kg}$ & & \\
\hline & & $\begin{array}{l}\mathrm{AM} 630 \\
\left(\mathrm{CB}_{2} \mathrm{R}\right. \\
\text { antagonist) }\end{array}$ & Mouse, ICR & LDB & $1,2,3 \mathrm{mg} / \mathrm{kg}$ & $\begin{array}{l}\uparrow \text { anxiogenic } \\
\text { response }\end{array}$ & {$[47]$} \\
\hline & \multirow[t]{5}{*}{$\begin{array}{l}\text { Chronic } \\
\text { treatment }\end{array}$} & Drug & Animal specie & $\begin{array}{l}\text { Experimental } \\
\text { test }\end{array}$ & Dosis & $\begin{array}{l}\text { Behavioral } \\
\text { changes }\end{array}$ & References \\
\hline & & \multirow{2}{*}{$\begin{array}{l}\text { AM630 } \\
\text { (CB }{ }_{2} \mathrm{R} \\
\text { antagonist) }\end{array}$} & \multirow[t]{2}{*}{ Mouse, ICR } & LDB & \multirow{2}{*}{$\begin{array}{l}1,2,3 \mathrm{mg} / \mathrm{kg} \\
\text { per } 12 \mathrm{~h} \\
(7 \text { days })\end{array}$} & \multirow{2}{*}{$\begin{array}{l}\downarrow \text { anxiogenic } \\
\text { response }\end{array}$} & \multirow[t]{2}{*}[47]{} \\
\hline & & & & EPM & & & \\
\hline & & \multirow{2}{*}{$\begin{array}{l}\text { JWH133 } \\
\text { (CB }{ }_{2} \mathrm{R} \text { agonist) }\end{array}$} & \multirow[t]{2}{*}{ Mouse, ICR } & LDB & \multirow{2}{*}{$\begin{array}{l}0.5,1,2 \mathrm{mg} / \mathrm{kg} \\
\text { per } 12 \mathrm{~h} \text { (7 days) }\end{array}$} & \multirow{2}{*}{$\begin{array}{l}\uparrow \text { anxiogenic } \\
\text { response }\end{array}$} & \multirow[t]{2}{*}{ [47] } \\
\hline & & & & EPM & & & \\
\hline \multicolumn{8}{|c|}{ Human studies } \\
\hline \multicolumn{2}{|l|}{ Variable } & \multicolumn{2}{|l|}{ Population } & \multicolumn{3}{|l|}{ Results } & References \\
\hline \multicolumn{2}{|c|}{$\begin{array}{l}\text { rs2070956 } \\
\text { polymorphism }\end{array}$} & \multicolumn{2}{|l|}{$\begin{array}{l}\text { Caucasian } \\
\text { (infant) }\end{array}$} & $\downarrow$ response to tl & he treatment & & {$[50]$} \\
\hline
\end{tabular}

Cnr2 KO: mouse lacking $C B_{2} R$ gene in the CNS with C57BL/6J background; LDB: light-dark box test; EPM: elevated plus-maze test; SD: experimental paradigm of social defeat; MB: marble-burying behavioral test. $\uparrow:$ increases; $\downarrow$ : decreases

Few clinical studies have been performed but with promising results. A relationship was found between the rs2070956 polymorphism of $\mathrm{CB}_{2} \mathrm{R}$ and a poorer response to treatment in children with anxiety disorders [50]. Taking together, more studies in both mice and humans are needed to further investigate the role of $\mathrm{CB}_{2} \mathrm{R}$ in anxiety disorders, especially from the perspective of its potential therapeutic suitability.

\section{Involvement of $\mathrm{CB}_{2} \mathrm{R}$ in depressive disorders}

In this section, it is essential to highlight the findings of experimental animal and human studies that revealed the potential therapeutic role of $\mathrm{CB}_{2} \mathrm{R}$ in depressive disorders. Genetic and pharmacological studies in rodents indicate that overexpression of $\mathrm{CB}_{2} \mathrm{R}$ is associated with increased resistance to stimuli that promote depressive-like behaviors. $\mathrm{CB}_{2} \mathrm{xP}$ mice (overexpressing $\mathrm{CB}_{2} \mathrm{R}$ ) showed reduced immobility time in acute models of depression (tail suspension and novelty-suppressed feeding tests) [39]. Similarly, mice lacking this receptor $\left(\mathrm{CB}_{2} \%\right.$ mice $)$ present a higher degree of vulnerability to develop depressive-like behavior in the tail suspension test [44]. The results found with the conditional knockout mouse lacking $\mathrm{CB}_{2} \mathrm{R}$ in dopaminergic 
neurons (DAT-Cnr2 ${ }^{-}$) are similar, that is, they present increased immobility time in the tail suspension and forced swimming tests, suggesting increased vulnerability to stimuli promoting depressive-like behaviors in rodents [51] (Table 2).

Table 2. Major findings supporting the involvement of $\mathrm{CB}_{2} \mathrm{R}$ in depressive disorders

\begin{tabular}{|c|c|c|c|c|c|c|}
\hline \multicolumn{7}{|l|}{ Animal studies } \\
\hline \multirow[t]{7}{*}{ Genetic studies } & $\begin{array}{l}\text { Genetic } \\
\text { manipulation }\end{array}$ & $\begin{array}{l}\text { Animal } \\
\text { specie }\end{array}$ & $\begin{array}{l}\text { Experimental } \\
\text { test }\end{array}$ & \multicolumn{2}{|c|}{ Behavioral changes } & References \\
\hline & $\mathrm{CB}_{2} \mathrm{xP}$ & Mouse, ICR & TST & \multicolumn{2}{|c|}{$\downarrow$ immobility time } & [39] \\
\hline & & & NSFT & \multicolumn{2}{|c|}{$\downarrow$ latency time and $\uparrow$ food $(\mathrm{g})$ consumption } & [39] \\
\hline & & & CMS & \multicolumn{2}{|c|}{$\uparrow$ resistance } & [39] \\
\hline & & & & \multicolumn{2}{|c|}{$\begin{array}{l}\text { ( } \uparrow \text { sucrose } 1 \% \text { consumption and } \\
\downarrow \text { immobility time in TST) }\end{array}$} & \\
\hline & $\mathrm{CB}_{2}^{-1-}$ & Mouse, ICR & TST & \multicolumn{2}{|c|}{$\uparrow$ immobility time } & [44] \\
\hline & DAT-Cnr2-- & $\begin{array}{l}\text { Mouse, } \\
\text { C57BL/6J }\end{array}$ & TST, FST & \multicolumn{2}{|c|}{$\uparrow$ immobility time } & [69] \\
\hline \multirow[t]{5}{*}{$\begin{array}{l}\text { Pharmacological } \\
\text { studies }\end{array}$} & Drug & $\begin{array}{l}\text { Animal } \\
\text { specie }\end{array}$ & $\begin{array}{l}\text { Experimental } \\
\text { test }\end{array}$ & Dosis & Behavioral changes & References \\
\hline & AM630 & Mouse, ICR & CMS & \multirow{2}{*}{$\begin{array}{l}1 \mathrm{mg} / \mathrm{kg} \\
\text { per } 12 \mathrm{~h} \\
(4 \text { weeks) }\end{array}$} & \multirow{2}{*}{$\begin{array}{l}\text { Antidepressive actions } \\
\text { ( } \uparrow \text { immobility time in TST } \\
\text { and } \uparrow \text { sucrose } 1 \% \text { consumption) }\end{array}$} & \multirow[t]{2}{*}[39]{} \\
\hline & $\begin{array}{l}\left(\mathrm{CB}_{2} \mathrm{R}\right. \\
\text { antagonist) }\end{array}$ & & & & & \\
\hline & & $\begin{array}{l}\text { Mouse, } \\
\text { BALB/c }\end{array}$ & CMS & \multirow{2}{*}{\multicolumn{2}{|c|}{$\begin{array}{l}3 \mathrm{mg} / \mathrm{kg} \quad \text { No effect } \\
\text { per } 24 \mathrm{~h} \\
(4 \text { weeks })\end{array}$}} & [45] \\
\hline & & C57BL/6J & & & & \\
\hline \multicolumn{7}{|l|}{ Human studies } \\
\hline Variable & \multicolumn{2}{|l|}{ Population } & \multicolumn{3}{|l|}{ Results } & References \\
\hline $\begin{array}{l}\text { Q63R } \\
\text { polymorphism }\end{array}$ & \multicolumn{2}{|l|}{ Japanese } & \multicolumn{3}{|l|}{$\uparrow$ incidence } & [45] \\
\hline $\mathrm{CB}_{2} \mathrm{R}$ expression & \multicolumn{2}{|l|}{ Caucasian } & \multicolumn{3}{|c|}{$\downarrow$ in DLPFC and amygdala } & {$[56]$} \\
\hline
\end{tabular}

TST: tail suspension test; NSFT: novelty suppressed feeding test; FST: forced swimming test; CMS: chronic mild stress

Another important strength supporting the role of $\mathrm{CB}_{2} \mathrm{R}$ in the development of depressive behaviors is provided by studies using the CMS model, the most relevant animal model of depression. This model induces behavioral and neurochemical alterations in rodents similar to the different signs and symptoms observed in depressive patients, such as anhedonia, reduced sexual activity, increased aggressiveness, reduced grooming, and detriment of neurogenesis processes, especially in the hippocampus [52, 53]. Exposure to this model does not induce any alteration in $\mathrm{CB}_{2} \mathrm{xP}$ mice in any of the parameters evaluated, immobility time in the tail suspension test, and consumption of a $1 \%$ sucrose solution (anhedonia), both typical traits of depressive-like behaviors in rodents [39].

Additionally, several studies were conducted to evaluate whether pharmacological manipulation of $\mathrm{CB}_{2} \mathrm{R}$ by the administration of a selective antagonist would reproduce a similar phenotype in wild-type mice to that observed in $\mathrm{CB}_{2} \mathrm{xP}$ mice. This assumption is based on the evidence supporting that administration of receptor antagonists produces long-term up-regulation of the blocked receptor [54, 55]. To this end, the effects of chronic administration of the $\mathrm{CB}_{2} \mathrm{R}$ antagonist AM630 [1 mg/(kg.12 h)] were evaluated in the CMS model. This study demonstrated how the administration of AM630 reversed depressive-like behavior [evaluated in the tail suspension test and the ingestion of a 1\% sucrose solution (anhedonia)] after 4 weeks of treatment, an effect accompanied by an increase of $C B_{2} R$ gene expression in the hippocampus [39]. In contrast to these data, it was previously shown that administration of AM630 [1 mg/(kg.24 h)] failed to exert any effect on sucrose consumption in CMS-exposed mice [41]. Again, these discrepancies could be due to notable differences between the two studies such as 1) the rodent strains employed (BALB/c, ICR), and 2) the dose and administration patterns evaluated [3 mg/(kg.24 h)] [41] in contrast to $1 \mathrm{mg} /(\mathrm{kg} \cdot 12 \mathrm{~h}$ ) [39].

In humans, the research team led by Onaivi [41] showed that there is a high incidence of the Q63R polymorphism of $\mathrm{CB}_{2} \mathrm{R}$ in Japanese depressive patients. Furthermore, a postmortem study performed in 
suicides revealed that there is a reduction of $\mathrm{CB}_{2} R$ gene expression in the dorsolateral prefrontal cortex and amygdala, key regions involved in decision making, impulsivity, and emotional reactivity, supporting the role that this receptor could play in several psychiatric diseases with an increased tendency to suicide, such as depression, schizophrenia, and bipolar disorder [56].

Together, these results highlight the involvement of $\mathrm{CB}_{2} \mathrm{R}$ in the emotional response and its potential utility as a new target for the treatment of depressive disorders.

\section{Involvement of $\mathrm{CB}_{2} \mathrm{R}$ in schizophrenia}

Currently, a large number of results support the involvement of $\mathrm{CB}_{2} \mathrm{R}$ in psychotic disorders. Clinically, significant reductions in $C B_{2} R$ gene expression were detected in peripheral mononuclear blood cells of schizophrenic patients in remission [57]. Also, an increased incidence of $\mathrm{CB}_{2} \mathrm{R}$ polymorphisms rs12744386 and rs2501432 was found in Japanese schizophrenic patients [42], and of rs2501432 and rs22229579 $\mathrm{CB}_{2} \mathrm{R}$ polymorphisms in the Han ethnic population in China [58]. The results of this latest study suggest that the $\mathrm{T}$ allele of the rs 2501432 polymorphism would have a protective role, especially in men. Conversely, the $\mathrm{T}$ allele of the rs2229549 polymorphism would constitute a risk factor for the development of schizophrenia. However, further studies failed to establish a relationship between additional polymorphisms in $\mathrm{CB}_{2} \mathrm{R}$ (rs6689530, rs34570472, Cnr2_ht1, Cnr2_ht2, and Cnr2_ht3) and schizophrenia in the Korean population, probably due to the small sample sizes included in them [59] (Table 3).

Table 3. Major findings supporting the involvement of $\mathrm{CB}_{2} \mathrm{R}$ in psychotic disorders

\begin{tabular}{|c|c|c|c|c|c|c|c|}
\hline \multicolumn{8}{|l|}{ Animal studies } \\
\hline \multirow[t]{4}{*}{ Genetic studies } & $\begin{array}{l}\text { Genetic } \\
\text { manipulation }\end{array}$ & \multicolumn{2}{|c|}{ Animal specie } & $\begin{array}{l}\text { Experimental } \\
\text { test }\end{array}$ & \multicolumn{2}{|c|}{ Behavioral changes } & References \\
\hline & \multirow[t]{3}{*}{$\mathrm{CB}_{2}^{-1-}$} & \multirow{3}{*}{\multicolumn{2}{|c|}{ Mouse, ICR }} & OF & \multicolumn{2}{|c|}{$\begin{array}{l}\uparrow \text { sensibility to cocaine-induced } \\
\text { hyperlocomotion }\end{array}$} & [44] \\
\hline & & & & SDIA & \multicolumn{2}{|c|}{$\begin{array}{l}\text { short and long-term memory } \\
\text { impairment }\end{array}$} & {$[44,71]$} \\
\hline & & & & PPI & $\uparrow \mathrm{PPI}$ & & \\
\hline \multirow[t]{6}{*}{$\begin{array}{l}\text { Pharmacological } \\
\text { studies }\end{array}$} & Drug & \multicolumn{2}{|c|}{ Animal specie } & $\begin{array}{l}\text { Experimental } \\
\text { test }\end{array}$ & Dosis & $\begin{array}{l}\text { Behavioral } \\
\text { changes }\end{array}$ & References \\
\hline & $\begin{array}{l}\mathrm{AM} 630 \\
\left(\mathrm{CB}_{2} \mathrm{R}\right.\end{array}$ & \multicolumn{2}{|c|}{$\begin{array}{l}\text { Mouse, } \\
\text { C57BL/6J }\end{array}$} & PPI & 3 and $30 \mathrm{mg} / \mathrm{kg}$ & $\begin{array}{l}\uparrow \text { alteration induced } \\
\text { by MK- } 801\end{array}$ & [42] \\
\hline & antagonist) & \multicolumn{2}{|c|}{ Mouse, ICR } & OF & $2 \mathrm{mg} / \mathrm{kg}$ & $\begin{array}{l}\uparrow M K-801 \text {-induced } \\
\text { hyperlocomotion }\end{array}$ & [70] \\
\hline & $\begin{array}{l}\text { JWH015 } \\
\text { (agonista } \\
\mathrm{CB}_{2} \mathrm{R} \text { ) }\end{array}$ & \multicolumn{2}{|c|}{ Mouse, BALB/c } & PPI & 1,3 and $10 \mathrm{mg} / \mathrm{kg}$ & $\begin{array}{l}\downarrow \text { alteration induced } \\
\text { by MK-801 }\end{array}$ & {$[67]$} \\
\hline & $\begin{array}{l}\text { JWH133 } \\
\text { (agonista }\end{array}$ & \multicolumn{2}{|c|}{ Mouse, ICR } & OF & $20 \mathrm{mg} / \mathrm{kg}$ & $\begin{array}{l}\downarrow \text { cocaine-induced } \\
\text { hyperlocomotion }\end{array}$ & [68] \\
\hline & $\left.\mathrm{CB}_{2} \mathrm{R}\right)$ & \multicolumn{2}{|c|}{$\begin{array}{l}\text { Mouse, } \\
\text { C57BL/6J }\end{array}$} & OF & $\begin{array}{l}10,20 \text { and } 30 \\
\mathrm{mg} / \mathrm{kg}\end{array}$ & $\begin{array}{l}\downarrow \text { cocaine-induced } \\
\text { hyperlocomotion }\end{array}$ & [69] \\
\hline \multicolumn{8}{|l|}{ Human studies } \\
\hline \multicolumn{3}{|l|}{ Parameter } & \multicolumn{2}{|c|}{ Population } & \multicolumn{2}{|l|}{ Results } & References \\
\hline \multicolumn{3}{|c|}{$\mathrm{CB}_{2} \mathrm{R}$ gene expression } & \multicolumn{2}{|c|}{ Caucasian } & \multicolumn{2}{|c|}{$\downarrow$ reduction in PBMCs } & {$[57]$} \\
\hline \multicolumn{3}{|l|}{ Polymorphism } & \multicolumn{2}{|c|}{ Population } & \multicolumn{2}{|l|}{ Results } & References \\
\hline \multicolumn{3}{|l|}{$\begin{array}{l}\text { rs12744386 } \\
\text { rs2501432 }\end{array}$} & \multicolumn{2}{|c|}{ Japanese } & \multicolumn{2}{|l|}{$\uparrow$ incidence } & [42] \\
\hline \multicolumn{3}{|l|}{ rs2501432 } & \multirow{2}{*}{\multicolumn{2}{|c|}{$\begin{array}{l}\text { Chinese } \\
\text { (Han ethnic group) }\end{array}$}} & \multicolumn{2}{|l|}{ Allele $\mathrm{T} \uparrow$ risk } & [58] \\
\hline \multicolumn{3}{|l|}{ rs22229579 } & & & \multicolumn{2}{|l|}{ Allele $T \downarrow$ risk } & \\
\hline \multicolumn{3}{|c|}{$\begin{array}{l}\text { rs6689530 rs34570472 Cnr2_ht1 Cnr2_ht2 } \\
\text { Cnr2_ht3 }\end{array}$} & \multicolumn{2}{|l|}{ Korean } & \multicolumn{2}{|l|}{ No effect } & [59] \\
\hline
\end{tabular}

The use of different animal models of schizophrenia supported the involvement of $\mathrm{CB}_{2} \mathrm{R}$ in this psychiatric disease. Early maternal deprivation constitutes an animal model for the study of schizophrenia by 
reproducing several symptoms (cognitive and attention alterations) observed in schizophrenic patients that translate into alterations in PPI, startle reflex, and latent inhibition [60,61]. These behavioral disturbances are accompanied by important neurobiological alterations in the hippocampus, increased number of astrocytes, neuronal degeneration, elevated corticosterone and 2-AG levels [62, 63], reduced $C B_{1} R$ gene expression, and increased $C B_{2} R$ gene expression [64].

One of the main tests used both in humans and rodents for the evaluation of attention-deficit associated with schizophrenic pathology is the PPI test in which reduced values are representative of the inability to filter the information presented by these patients. In this regard, the administration in rodents of methamphetamine or MK-801, a non-competitive $N$-methyl- $D$-aspartate (NMDA) glutamatergic receptor antagonist, are two highly accepted models of schizophrenia producing a reduction in PPI values similar to those observed in schizophrenic patients $[65,66]$. While $\mathrm{CB}_{2} \mathrm{R}$ blockade using the $\mathrm{CB}_{2} \mathrm{R}$ antagonist AM630 $(3 \mathrm{mg} / \mathrm{kg}$ and $30 \mathrm{mg} / \mathrm{kg}$ ) does not trigger alterations per se in PPI, it exacerbates MK-801- or methamphetamine-induced alterations in C57BL/6J mice [42]. Another complementary study shows that the agonist JWH015 (1, 3, and $10 \mathrm{mg} / \mathrm{kg}$ ) improves MK-801-induced impairment in PPI, without presenting any effects on its own [67]. The fact that this effect is blocked by AM630, but not by the $\mathrm{CB}_{1} \mathrm{R}$ antagonist AM251, confirms the involvement of $\mathrm{CB}_{2} \mathrm{R}$.

Hyperlocomotion induced by psychostimulants or by MK-801 is another animal model of schizophrenia. The results obtained using this model have been promising. On the one hand, the administration of the agonist JWH133 dose-dependently reduces cocaine-induced hyperlocomotion in wild-type mice [68, 69]. On the other hand, AM630 at doses that do not affect motor activity $(2 \mathrm{mg} / \mathrm{kg})$ worsens MK-801-induced hyperlocomotion [70]. These results strongly suggest that the inhibition of $\mathrm{CB}_{2} \mathrm{R}$ function potentially precipitates schizophrenia-like symptoms in rodents when combined with risk factors such as inhibition of glutamatergic transmission induced by NMDA receptor antagonists.

Studies carried out in genetically modified mice have confirmed the involvement of $\mathrm{CB}_{2} \mathrm{R}$ in schizopsychotic disorders. $\mathrm{CB}_{2}^{-\%}$ mice present increased vulnerability to hyperlocomotion induced by acute cocaine administration, in addition to PPI and cognitive alterations [44, 71]. Moreover, treatment with the antipsychotic risperidone normalizes PPI values in $\mathrm{CB}_{2}^{-1-}$ mice. All these facts suggest that genetic deletion of $\mathrm{CB}_{2} \mathrm{R}$ could be a useful tool as an animal model of schizophrenia [44].

Recently, it was shown that $\mathrm{CB}_{2} \mathrm{R}$ is critical for acetylcholine muscarinic 4 (M4) receptor agonists, such as compound UV0467154, to exhibit their antipsychotic actions [72]. This study indicates that agonist-regulated stimulation of M4 receptors would increase the release of endogenous cannabinoids, in turn activating $\mathrm{CB}_{2} \mathrm{R}$, which would eventually inhibit dopamine release, a fact that would be involved in the antipsychotic efficacy of $\mathrm{M} 4$ agonists. Consequently, blocking $\mathrm{CB}_{2} \mathrm{R}$ by the antagonist $\mathrm{AM} 630$ would prevent $\mathrm{M} 4$ agonists to present antipsychotic effects. This finding highlights that $\mathrm{CB}_{2} \mathrm{R}$ is indispensable in the regulation of dopamine concentrations altered in this disease, pointing out its potential therapeutic utility in the treatment of psychotic disorders.

Taken together, these findings suggest that $\mathrm{CB}_{2} \mathrm{R}$ is crucial in the regulation of symptoms related to psychotic disorders. Further pharmacological studies, such as those evaluating the additive effects of $\mathrm{CB}_{2} \mathrm{R}$ agonist/antagonist combinations with antipsychotics (e.g., risperidone), are needed to clarify the role of pharmacological modulation of $\mathrm{CB}_{2} \mathrm{R}$ in the treatment of psychotic disorders.

\section{Involvement of $\mathrm{CB}_{2} \mathrm{R}$ in bipolar disorder}

To date, few studies focused on investigating the possible link between $\mathrm{CB}_{2} \mathrm{R}$ and bipolar disorder. There is only one study in which the incidence of three polymorphisms of the gene coding for $\mathrm{CB}_{2} \mathrm{R}, \mathrm{rs} 2501432$ (315>G; Arg63Gln), rs41311993 (524C>A; Leu133Ile) and rs2229579 (1073C>T; Tyr316His), was evaluated in 80 patients with bipolar disorder [73]. The results allowed to establish a direct relationship between the rs41311993 (524C>A) polymorphism of $\mathrm{CB}_{2} \mathrm{R}$ and bipolar disorder. This polymorphism consists of the substitution of the amino acid leucine by isoleucine at position 133, involved in the structural stability of the receptor since it allows the formation of hydrophobic interactions between helix III with the rest of the 
7 transmembrane domains (except helix I). Helix III, therefore, plays a primordial role in the regulation of $\mathrm{CB}_{2} \mathrm{R}$ activity, participating in its interaction with the $\mathrm{G}$ protein-coupled to it. Consequently, the presence of this polymorphism could affect the structural stability of the receptor, as well as its interaction with the $\mathrm{G}$ protein. This finding is the first evidence to indicate that $\mathrm{CB}_{2} \mathrm{R}$ may be involved in the etiology of bipolar disorder. Further studies, both clinical and preclinical, are needed to investigate the involvement of $\mathrm{CB}_{2} \mathrm{R}$ in this psychiatric disorder.

\section{Advances in the identification of molecular mechanisms related to the involvement of $\mathrm{CB}_{2} \mathrm{R}$ in neuropsychiatry}

$\mathrm{CB}_{2} \mathrm{R}$ was identified in different cell types (neurons, glia, and astroglia) of the as well as its interaction with targets classically related to the response to stress, anxiety, depression, and schizophrenia, such as the hypothalamic-pituitary-adrenal (HPA) axis, processes of neurogenesis, and neuronal plasticity, and the GABAergic, dopaminergic and serotonergic neurotransmitter systems.

\section{Expression of $\mathrm{CB}_{2} \mathrm{R}$ in neurons, glia, and astroglia}

The identification of the pharmacological properties of $\mathrm{CB}_{2} \mathrm{R}$ stimulated great interest in determining the cell type in which this receptor is expressed, not without some controversy. The main limitation in interpreting the results of these studies is antibody selectivity [74], a common problem for many G protein-coupled receptors [75].

Despite these limitations, several studies revealed that $\mathrm{CB}_{2} \mathrm{R}$ localizes to hippocampal glutamatergic [76, 77], cortical pyramidal [37, 56], cholinergic [78], and dopaminergic [79-82] as well as in other neuronal types in the brainstem [36] and cerebellum [37]. Furthermore, human postmortem studies identified $\mathrm{CB}_{2} \mathrm{R}$ in microglia in the cerebellum [83] and astrocytes in the dorsolateral prefrontal cortex [56].

In mice, $\mathrm{CB}_{2} \mathrm{R}$ was detected in the astroglia of the nucleus accumbens and ventral tegmental area [79]. Complementary studies show that this expression is significantly upregulated in the presence of certain types of lesions in both reactive microglia and activated astrocytes [84-86], which has served to refute its role in diseases in which the neuroinflammatory component is important, such as schizophrenia (for review $[87,88]$ ).

\section{$\mathrm{CB}_{2} \mathrm{R}$ and the HPA axis}

The HPA axis is one of the main elements of the response to stressful stimuli, modulating endocrine, autonomic, and behavioral responses to stress. Alterations in the HPA axis were associated with increased levels of anxiety and stress response in rodents and patients with anxiety disorders [89, 90].

Recent studies showed that $\mathrm{CB}_{2} \mathrm{R}$ is involved in the regulation of the HPA axis. In an animal model of stress induced by movement restriction (in a cylinder for $30 \mathrm{~min}$ ), it was found that the $\mathrm{CB}_{2} \mathrm{xP}$ mouse (overexpressing $\mathrm{CB}_{2} \mathrm{R}$ ) shows no changes in corticotropin-releasing factor (CRF) gene expression in the paraventricular nucleus (PVN), and only a slight increase in pro-opiomelanocortin (POMC) gene expression in the arcuate nucleus (ARC) (22\%). However, in control mice, there is an $82 \%$ increase of CRF in the PVN and a $42 \%$ increase of POMC in the ARC [43]. On the other hand, it was found that exposure to certain stressful situations increases $C B_{2} R$ gene expression in the hippocampus, an area closely related to the HPA axis activity $[48,64]$.

In humans, only one study evaluated $\mathrm{CB}_{2} R$ gene expression in human adrenal tissue as well as in cultures of the NCI-H295R cell lines, a widely accepted model for human adrenocortical studies. The presence of $\mathrm{CB}_{2} \mathrm{R}$ could not be detected in both types of samples [91].

These results highlight the need to perform further experimental and clinical studies that explore the role of $\mathrm{CB}_{2} \mathrm{R}$ in the regulation of the HPA axis. Evaluation of how the HPA axis response to stressful stimuli is modified by administration of $\mathrm{CB}_{2} \mathrm{R}$ agonists/antagonists would be a promising starting point.

\section{$\mathrm{CB}_{2} \mathrm{R}$ and neurogenesis}

Neuroplasticity is one of the processes compromised in a wide variety of neuropsychiatric disorders [92-95]. The hippocampus represents a region of interest because of its high plasticity [96]. A reduction of $C B_{2} R$ 
gene expression was found in the hippocampus of rodents exposed to the animal model of CMS along with a reduction of brain-derived neurotrophic factor (BDNF). Both reductions are blocked by the administration of the $\mathrm{CB}_{2} \mathrm{R}$ antagonist AM630 (1 mg/kg) [39]. In this study, $\mathrm{CB}_{2} \mathrm{xP}$ mice presented increased levels of BDNF in the hippocampus. Surprisingly, these levels are not modified after exposure to CMS, as is the case in control mice. These data indicate that the increased resistance of $\mathrm{CB}_{2} \mathrm{xP}$ mice to develop depressive behaviors could be related, at least in part, to its actions on neuronal plasticity. Indeed, recent studies show that $\mathrm{CB}_{2} \mathrm{R}$ regulates hyperpolarization phenomena in hippocampal neurons [cornu ammonis 3 (CA3) and cornu ammonis 2 (CA2) regions]. This phenomenon is independent of excitatory glutamatergic and inhibitory GABAergic synaptic transmission and therefore has been proposed as an intrinsic plasticity mechanism that would negatively modify the excitability of neurons in CA3. The reduction of the excitability of these neurons would possibly enhance plasticity [76].

Furthermore, $\mathrm{CB}_{2} \mathrm{R}$ appears to regulate different key signaling pathways in plasticity processes, such as the phospholipase A and C pathway and phosphoinositol-3 kinase and mitogen-activated protein kinases (MAPKs) [97], supporting their role in the intracellular regulation of calcium homeostasis and mitochondrial functions, as well as the control of trophic processes, excitability and neuronal signaling [98]. Moreover, additional results revealed that activation of $\mathrm{CB}_{2} \mathrm{R}$ in the brain stimulates glucose reuptake [99] and reduces oxidative stress [100].

Taken together, all these findings suggest that $\mathrm{CB}_{2} \mathrm{R}$ may result in a new therapeutic target in the treatment of several diseases with impaired neuroplasticity processes.

\section{$\mathrm{CB}_{2} \mathrm{R}$ and GABAergic neurotransmission}

In parallel, the interaction between $\mathrm{CB}_{2} \mathrm{R}$ and GABA, the main CNS inhibitory neurotransmitter involved in a wide variety of psychiatric diseases, were studied [101-106].

Pharmacological or genetic manipulation of $\mathrm{CB}_{2} \mathrm{R}$ modifies GABAergic transmission. Chronic administration of the antagonist $\mathrm{AM} 630$ increased $\mathrm{CB}_{2} \mathrm{R}$ levels in the amygdala and enhanced the expression of GABA A receptor subunits alpha $2\left(\mathrm{GABA}_{A} \alpha 2\right)$, and gamma $2\left(\mathrm{GABA}_{A} \gamma 2\right)$, related to the anxiolytic effects of GABA. In contrast, the agonist JWH133 produces changes in the opposite direction [47]. Additionally, $\mathrm{CB}_{2} \mathrm{xP}$ mice show higher gene expression of both GABAergic subunits, both in the hippocampus and amygdala, which explains, at least in part, the absence of anxiolytic effects after alprazolam administration in these rodents [43].

Furthermore, some studies using electrophysiological techniques indicate that $\mathrm{CB}_{2} \mathrm{R}$ regulates GABAergic inhibition in the medial entorhinal cortex of rats [101]. The administration of the agonist JWH133 abolishes GABAergic inhibition which can be reversed if the antagonist AM630 is administered. Complementarily, the administration of the inverse agonist JTE-907 increases GABAergic transmission in this region. These effects are not observed with the administration of $\mathrm{CB}_{1} \mathrm{R}$ agonists, confirming the role of $\mathrm{CB}_{2} \mathrm{R}$ in the regulation of GABAergic transmission in this brain region.

\section{$\mathrm{CB}_{2} \mathrm{R}$ and dopaminergic and serotonergic neurotransmission}

The identification of gene and protein expression of $\mathrm{CB}_{2} \mathrm{R}$ in certain neuronal types, together with the effects observed after its pharmacological and genetic manipulation, has stimulated studies to elucidate the role of $\mathrm{CB}_{2} \mathrm{R}$ in dopaminergic and serotonergic neurotransmission.

The absence of $\mathrm{CB}_{2} \mathrm{R}$ generates a series of alterations in the gene expression of different elements of dopaminergic transmission. The $\mathrm{CB}_{2} /$ mouse shows increased gene expression of the dopaminergic D2 receptor in the prefrontal cortex, which could contribute, at least in part, to the behavioral alterations observed in this rodent [44]. Also, the use of the conditioned KO mouse demonstrated the inhibitory role of $\mathrm{CB}_{2} \mathrm{R}$ in dopaminergic neurons [51].

Alterations in gene expression of monoamine oxidase A (MAO-A) enzyme, serotonin transporter, and serotonergic 5-hydroxytryptamine $2 \mathrm{C}\left(5-\mathrm{HT}_{2 \mathrm{C}}\right)$ receptor in the dorsal raphe of $\mathrm{CB}_{2}^{-1-}$ mice have been observed. Also, alterations of the serotonergic 5-hydroxytryptamine $2 \mathrm{~A}\left(5-\mathrm{HT}_{2 \mathrm{~A}}\right)$ receptor in the prefrontal cortex and the enzymes MAO-A and catechol-0-methyltransferase and the serotonergic 5-hydroxytryptamine $1 \mathrm{~B}\left(5-\mathrm{HT}_{1 \mathrm{~B}}\right)$ receptor in the amygdala of $\mathrm{CB}_{2} \%$ mice are present $[44,49]$. 
Electrophysiology studies suggest that the $\mathrm{CB}_{2}$ R agonist GP 1a increases gene and protein expression of the serotonergic 5- $\mathrm{HT}_{2 \mathrm{~A}}$ receptor in the rat dorsolateral prefrontal cortex, which is blocked by the administration of the $\mathrm{CB}_{2} \mathrm{R}$ antagonist PD 198306. This increase appears to be related to activation of the extracellular regulated kinase $1 / 2(E R K 1 / 2)$ signaling pathway induced by $\mathrm{CB}_{2} \mathrm{R}$ activation $[107,108]$. Cortical $5-\mathrm{HT}_{2 \mathrm{~A}}$ receptor activity was linked to stress response, anxiety, depression, and schizopsychotic symptoms present in various disorders.

Taken together, these results provide relevant information on the molecular mechanisms by which $\mathrm{CB}_{2} \mathrm{R}$ activation or blockade may be relevant in the pathophysiology of different psychiatric disorders.

\section{Conclusions}

In summary, the findings included in this review highlight the potential therapeutic suitability of $\mathrm{CB}_{2} \mathrm{R}$ in a wide variety of psychiatric disorders, including anxiety disorders, depressive disorders, schizophrenia, and disorders involving cognitive impairment. An additional value of $\mathrm{CB}_{2} \mathrm{R}$ pharmacological manipulation is the fact that, contrary to $\mathrm{CB}_{1} \mathrm{R}$ activation, does not induce psychotropic effects. The availability of agonist/ antagonist compounds of this receptor, along with recent allosteric modulators, represents a valuable tool for further experimental and preclinical studies to finally elucidate the role of the pharmacological regulation of $\mathrm{CB}_{2} \mathrm{R}$ in psychiatry. Besides, the few clinical trials conducted to date showed that these compounds are well tolerated, at least at the doses and in the pathologies tested $[109,110]$. Nonetheless, future studies are needed to evaluate safety in neuropsychiatric disorders.

\section{Abbreviations}

2-AG: 2-arachidonoyl glycerol

5- $\mathrm{HT}_{2 \mathrm{~A}}:$ 5-hydroxytryptamine $2 \mathrm{~A}$

$\mathrm{CB}_{1} \mathrm{R}$ : cannabinoid receptor 1

$\mathrm{CB}_{2} \mathrm{R}$ : cannabinoid receptor 2

CMS: chronic mild stress

CNS: central nervous system

ECS: endogenous cannabinoid system

EPM: elevated plus-maze test

HPA: hypothalamic-pituitary-adrenal

ICR: institute of cancer research

LDB: light-dark box test

M4: acetylcholine muscarinic 4

OF: open field test

PPI: prepulse inhibition

TST: tail suspension test

\section{Declarations}

\section{Acknowledgments}

We thank all participants in this study. We greatly appreciated Biorender for helping to create figure 1.

\section{Author contributions}

MSGG and JM conceived the presented idea. MSGG took the lead in writing the manuscript. FN and AG wrote the manuscript in consultation with MSGG. All authors provided critical feedback and helped shape the research, analysis, and manuscript. 


\section{Conflicts of interest}

The authors declare no conflict of interest.

\section{Ethical approval}

Not applicable.

\section{Consent to participate}

Not applicable.

\section{Consent to publication}

Not applicable.

\section{Availability of data and materials}

Not applicable.

\section{Funding}

Not applicable.

\section{Copyright}

(c) The Author(s) 2021.

\section{References}

1. Devane WA, Hanus L, Breuer A, Pertwee RG, Stevenson LA, Griffin G, et al. Isolation and structure of a brain constituent that binds to the cannabinoid receptor. Science. 1992;258:1946-9.

2. Mechoulam R, Ben-Shabat S, Hanus L, Ligumsky M, Kaminski NE, Schatz AR, et al. Identification of an endogenous 2-monoglyceride, present in canine gut, that binds to cannabinoid receptors. Biochem Pharmacol. 1995;50:83-90.

3. Sugiura T, Kondo S, Sukagawa A, Nakane S, Shinoda A, Itoh K, et al. 2-Arachidonoylglycerol: a possible endogenous cannabinoid receptor ligand in brain. Biochem Biophys Res Commun. 1995;215:89-97.

4. Bracey MH, Hanson MA, Masuda KR, Stevens RC, Cravatt BF. Structural adaptations in a membrane enzyme that terminates endocannabinoid signaling. Science. 2002;298:1793-6.

5. Cravatt BF, Giang DK, Mayfield SP, Boger DL, Lerner RA, Gilula NB, et al. Molecular characterization of an enzyme that degrades neuromodulatory fatty-acid amides. Nature. 1996;384:83-7.

6. Dinh TP, Carpenter D, Leslie FM, Freund TF, Katona I, Sensi SL, et al. Brain monoglyceride lipase participating in endocannabinoid inactivation. Proc Natl Acad Sci U S A. 2002;99:10819-24.

7. Dinh TP, Kathuria S, Piomelli D. RNA interference suggests a primary role for monoacylglycerol lipase in the degradation of the endocannabinoid 2-arachidonoylglycerol. Mol Pharmacol. 2004;66:1260-4.

8. Gulyas AI, Cravatt BF, Bracey MH, Dinh TP, Piomelli D, Boscia F, et al. Segregation of two endocannabinoidhydrolyzing enzymes into pre- and postsynaptic compartments in the rat hippocampus, cerebellum and amygdala. Eur J Neurosci. 2004;20:441-58.

9. Saario SM, Salo OM, Nevalainen T, Poso A, Laitinen JT, Järvinen T, et al. Characterization of the sulfhydrylsensitive site in the enzyme responsible for hydrolysis of 2-arachidonoyl-glycerol in rat cerebellar membranes. Chem Biol. 2005;12:649-56.

10. Herkenham M, Lynn AB, Johnson MR, Melvin LS, de Costa BR, Rice KC. Characterization and localization of cannabinoid receptors in rat brain: a quantitative in vitro autoradiographic study. J Neurosci. 1991;11:563-83.

11. Munro S, Thomas KL, Abu-Shaar M. Molecular characterization of a peripheral receptor for cannabinoids. Nature. 1993;365:61-5. 
12. Johns DG, Behm DJ, Walker DJ, Ao Z, Shapland EM, Daniels DA, et al. The novel endocannabinoid receptor GPR55 is activated by atypical cannabinoids but does not mediate their vasodilator effects. $\mathrm{Br}$ J Pharmacol. 2007;152:825-31.

13. Ryberg E, Larsson N, Sjögren S, Hjorth S, Hermansson NO, Leonova J, et al. The orphan receptor GPR55 is a novel cannabinoid receptor. Br J Pharmacol. 2007;152:1092-101.

14. Zygmunt PM, Petersson J, Andersson DA, Chuang H, Sørgård M, Di Marzo V, et al. Vanilloid receptors on sensory nerves mediate the vasodilator action of anandamide. Nature. 1999;400:452-7.

15. Muller C, Morales P, Reggio PH. Cannabinoid ligands targeting TRP channels. Front Mol Neurosci. 2019;11:487.

16. Bisogno T, Ligresti A, Di Marzo V. The endocannabinoid signalling system: biochemical aspects. Pharmacol Biochem Behav. 2005;81:224-38.

17. Freund TF, Katona I, Piomelli D. Role of endogenous cannabinoids in synaptic signaling. Physiol Rev. 2003;83:1017-66.

18. Piomelli D. The molecular logic of endocannabinoid signalling. Nat Rev Neurosci. 2003;4:873-84.

19. Mailleux P, Vanderhaeghen JJ. Distribution of neuronal cannabinoid receptor in the adult rat brain: a comparative receptor binding radioautography and in situ hybridization histochemistry. Neuroscience. 1992;48:655-68.

20. Glass M, Dragunow M, Faull RL. Cannabinoid receptors in the human brain: a detailed anatomical and quantitative autoradiographic study in the fetal, neonatal and adult human brain. Neuroscience. 1997;77:299-318.

21. Heim ME, Queisser W, Altenburg HP. Randomized crossover study of the antiemetic activity of levonantradol and metoclopramide in cancer patients receiving chemotherapy. Cancer Chemother Pharmacol. 1984;13:123-5.

22. Walsh D, Nelson KA, Mahmoud FA. Established and potential therapeutic applications of cannabinoids in oncology. Support Care Cancer. 2003;11:137-43.

23. Timpone JG, Wright DJ, Li N, Egorin MJ, Enama ME, Mayers J, et al. The safety and pharmacokinetics of single-agent and combination therapy with megestrol acetate and dronabinol for the treatment of HIV wasting syndrome. The DATRI 004 study group. Division of AIDS treatment research initiative. AIDS Res Hum Retroviruses. 1997;13:305-15.

24. Abrams DI, Hilton JF, Leiser RJ, Shade SB, Elbeik TA, Aweeka FT, et al. Short-term effects of cannabinoids in patients with HIV-1 infection: a randomized, placebo-controlled clinical trial. Ann Intern Med. 2003;139:258-66.

25. Wallace MS, Marcotte TD, Umlauf A, Gouaux B, Atkinson JH. Efficacy of inhaled cannabis on painful diabetic neuropathy. J Pain. 2015;16:616-27.

26. Langford RM, Mares J, Novotna A, Vachova M, Novakova I, Notcutt W, et al. A double-blind, randomized, placebo-controlled, parallel-group study of THC/CBD oromucosal spray in combination with the existing treatment regimen, in the relief of central neuropathic pain in patients with multiple sclerosis. J Neurol. 2013;260:984-97.

27. Borgan F, Kokkinou $\mathrm{M}$, Howes $\mathrm{O}$. The cannabinoid $\mathrm{CB}_{1}$ receptor in schizophrenia. Biol Psychiatry Cogn Neurosci Neuroimaging. 2020; [Epub ahead of print].

28. Shearman LP, Rosko KM, Fleischer R, Wang J, Xu S, Tong XS, et al. Antidepressant-like and anorectic effects of the cannabinoid $\mathrm{CB}_{1}$ receptor inverse agonist AM251 in mice. Behav Pharmacol. 2003;14:573-82.

29. Steiner MA, Marsicano G, Nestler EJ, Holsboer F, Lutz B, Wotjak CT. Antidepressant-like behavioral effects of impaired cannabinoid receptor type 1 signaling coincide with exaggerated corticosterone secretion in mice. Psychoneuroendocrinology. 2008;33:54-67. 
30. Steiner MA, Marsicano G, Wotjak CT, Lutz B. Conditional cannabinoid receptor type 1 mutants reveal neuron subpopulation-specific effects on behavioral and neuroendocrine stress responses. Psychoneuroendocrinology. 2008;33:1165-70.

31. Chakrabarti A, Onaivi ES, Chaudhuri G. Cloning and sequencing of a cDNA encoding the mouse braintype cannabinoid receptor protein. DNA Seq. 1995;5:385-8.

32. Derocq JM, Ségui M, Marchand J, Le Fur G, Casellas P. Cannabinoids enhance human B-cell growth at low nanomolar concentrations. FEBS Lett. 1995;369:177-82.

33. Schatz AR, Lee $M$, Condie RB, Pulaski JT, Kaminski NE. Cannabinoid receptors $\mathrm{CB}_{1}$ and $\mathrm{CB}_{2}$ : a characterization of expression and adenylate cyclase modulation within the immune system. Toxicol Appl Pharmacol. 1997;142:278-87.

34. Griffin G, Wray EJ, Tao Q, McAllister SD, Rorrer WK, Aung MM, et al. Evaluation of the cannabinoid $\mathrm{CB}_{2}$ receptor-selective antagonist, SR144528: further evidence for cannabinoid $\mathrm{CB}_{2}$ receptor absence in the rat central nervous system. Eur J Pharmacol. 1999;377:117-25.

35. Carlisle SJ, Marciano-Cabral F, Staab A, Ludwick C, Cabral GA. Differential expression of the $\mathrm{CB}_{2}$ cannabinoid receptor by rodent macrophages and macrophage-like cells in relation to cell activation. Int Immunopharmacol. 2002;2:69-82.

36. Van Sickle MD, Duncan M, Kingsley PJ, Mouihate A, Urbani P, Mackie K, et al. Identification and functional characterization of brainstem cannabinoid $\mathrm{CB}_{2}$ receptors. Science. 2005;310:329-32.

37. Gong JP, Onaivi ES, Ishiguro $\mathrm{H}$, Liu QR, Tagliaferro PA, Brusco A, et al. Cannabinoid $\mathrm{CB}_{2}$ receptors: immunohistochemical localization in rat brain. Brain Res. 2006;1071:10-23.

38. Onaivi ES. Neuropsychobiological evidence for the functional presence and expression of cannabinoid $\mathrm{CB}_{2}$ receptors in the brain. Neuropsychobiology. 2006;54:231-46.

39. García-Gutiérrez MS, Pérez-Ortiz JM, Gutiérrez-Adán A, Manzanares J. Depression-resistant endophenotype in mice overexpressing cannabinoid $\mathrm{CB}_{2}$ receptors. Br J Pharmacol. 2010;160:1773-84.

40. Ishiguro $\mathrm{H}$, Iwasaki S, Teasenfitz L, Higuchi S, Horiuchi Y, Saito T, et al. Involvement of cannabinoid $\mathrm{CB}_{2}$ receptor in alcohol preference in mice and alcoholism in humans. Pharmacogenomics J. 2007;7:380-5.

41. Onaivi ES, Ishiguro H, Gong JP, Patel S, Meozzi PA, Myers L, et al. Brain neuronal $\mathrm{CB}_{2}$ cannabinoid receptors in drug abuse and depression: from mice to human subjects. PLoS ONE. 2008;3:e1640.

42. Ishiguro $\mathrm{H}$, Horiuchi $Y$, Ishikawa $\mathrm{M}$, Koga $\mathrm{M}$, Imai $\mathrm{K}$, Suzuki $\mathrm{Y}$, et al. Brain cannabinoid $\mathrm{CB}_{2}$ receptor in schizophrenia. Biol Psychiatry. 2010;67:974-82.

43. García-Gutiérrez MS, Manzanares J. Overexpression of $\mathrm{CB}_{2}$ cannabinoid receptors decreased vulnerability to anxiety and impaired anxiolytic action of alprazolam in mice. J Psychopharmacol. 2011;25:111-20.

44. Ortega-Alvaro A, Aracil-Fernández A, García-Gutiérrez MS, Navarrete F, Manzanares J. Deletion of $\mathrm{CB}_{2}$ cannabinoid receptor induces schizophrenia-related behaviors in mice. Neuropsychopharmacology. 2011;36:1489-504.

45. Onaivi ES, Ishiguro H, Gong JP, Patel S, Meozzi PA, Myers L, et al. Functional expression of brain neuronal $\mathrm{CB}_{2}$ cannabinoid receptors are involved in the effects of drugs of abuse and in depression. Ann N Y Acad Sci. 2008;1139:434-49.

46. Valenzano KJ, Tafesse L, Lee G, Harrison JE, Boulet JM, Gottshall SL, et al. Pharmacological and pharmacokinetic characterization of the cannabinoid receptor 2 agonist, GW405833, utilizing rodent models of acute and chronic pain, anxiety, ataxia and catalepsy. Neuropharmacology. 2005;48:658-72.

47. García-Gutiérrez MS, García-Bueno B, Zoppi S, Leza JC, Manzanares J. Chronic blockade of cannabinoid $\mathrm{CB}_{2}$ receptors induces anxiolytic-like actions associated with alterations in $\mathrm{GABA}_{\mathrm{A}}$ receptors. $\mathrm{Br} \mathrm{J}$ Pharmacol. 2012;165:951-64.

48. Robertson JM, Achua JK, Smith JP, Prince MA, Staton CD, Ronan PJ, et al. Anxious behavior induces elevated hippocampal $\mathrm{CB}_{2}$ receptor gene expression. Neuroscience. 2017;352:273-84. 
49. Rodríguez-Arias M, Navarrete F, Blanco-Gandia MC, Arenas MC, Aguilar MA, Bartoll-Andrés A, et al. Role of $\mathrm{CB}_{2}$ receptors in social and aggressive behavior in male mice. Psychopharmacology (Berl). 2015;232:3019-31.

50. Lester KJ, Coleman JR, Roberts S, Keers R, Breen G, Bögels S, et al. Genetic variation in the endocannabinoid system and response to cognitive behavior therapy for child anxiety disorders. Am J Med Genet B Neuropsychiatr Genet. 2017;174:144-55.

51. Liu QR, Canseco-Alba A, Zhang HY, Tagliaferro P, Chung M, Dennis E, et al. Cannabinoid type 2 receptors in dopamine neurons inhibits psychomotor behaviors, alters anxiety, depression and alcohol preference. Sci Rep. 2017;7:17410.

52. Papp M, Nalepa I, Antkiewicz-Michaluk L, Sánchez C. Behavioural and biochemical studies of citalopram and WAY 100635 in rat chronic mild stress model. Pharmacol Biochem Behav. 2002;72:465-74.

53. Papp M, Moryl E, Willner P. Pharmacological validation of the chronic mild stress model of depression. Eur J Pharmacol. 1996;296:129-36.

54. Neisewander JL, Rowlett JK, Nonneman AJ, Bardo MT. Up-regulation of opiate receptors following chronic naltrexone treatment in mature and aged male and female rats. Prog Clin Biol Res. 1989;292:471-6.

55. Patel M, Gomes B, Patel C, Yoburn BC. Antagonist-induced micro-opioid receptor up-regulation decreases G-protein receptor kinase-2 and dynamin-2 abundance in mouse spinal cord. Eur J Pharmacol. 2002;446:37-42.

56. García-Gutiérrez MS, Navarrete F, Navarro G, Reyes-Resina I, Franco R, Lanciego JL, et al. Alterations in gene and protein expression of cannabinoid $\mathrm{CB}_{2}$ and GPR55 receptors in the dorsolateral prefrontal cortex of suicide victims. Neurotherapeutics. 2018;15:796-806.

57. Bioque M, García-Bueno B, Macdowell KS, Meseguer A, Saiz PA, Parellada M, et al. Peripheral endocannabinoid system dysregulation in first-episode psychosis. Neuropsychopharmacology. 2013;38:2568-77.

58. Tong D, He S, Wang L, Jin L, Si P, Cheng X. Association of single-nucleotide polymorphisms in the cannabinoid receptor 2 gene with schizophrenia in the Han Chinese population. J Mol Neurosci. 2013;51:454-60.

59. Bae JS, Kim JY, Park BL, Kim JH, Kim B, Park CS, et al. Genetic association analysis of Cnr1 and Cnr2 polymorphisms with schizophrenia in a Korean population. Psychiatr Genet. 2014;24:225-9.

60. Ellenbroek BA, de Bruin NM, van Den Kroonenburg PT, van Luijtelaar EL, Cools AR. The effects of early maternal deprivation on auditory information processing in adult wistar rats. Biol Psychiatry. 2004;55:701-7.

61. Garner B, Wood SJ, Pantelis C, van den Buuse M. Early maternal deprivation reduces prepulse inhibition and impairs spatial learning ability in adulthood: no further effect of post-pubertal chronic corticosterone treatment. Behav Brain Res. 2007;176:323-32.

62. López-Gallardo M, Llorente R, Llorente-Berzal A, Marco EM, Prada C, Di Marzo V, et al. Neuronal and glial alterations in the cerebellar cortex of maternally deprived rats: gender differences and modulatory effects of two inhibitors of endocannabinoid inactivation. Dev Neurobiol. 2008;68:1429-40.

63. Llorente R, Llorente-Berzal A, Petrosino S, Marco EM, Guaza C, Prada C, et al. Gender-dependent cellular and biochemical effects of maternal deprivation on the hippocampus of neonatal rats: a possible role for the endocannabinoid system. Dev Neurobiol. 2008;68:1334-47.

64. Suárez J, Llorente R, Romero-Zerbo SY, Mateos B, Bermúdez-Silva FJ, de Fonseca FR, et al. Early maternal deprivation induces gender-dependent changes on the expression of hippocampal $\mathrm{CB}_{1}$ and $\mathrm{CB}_{2}$ cannabinoid receptors of neonatal rats. Hippocampus. 2009;19:623-32.

65. Errico F, Rossi S, Napolitano F, Catuogno V, Topo E, Fisone G, et al. D-aspartate prevents corticostriatal long-term depression and attenuates schizophrenia-like symptoms induced by amphetamine and MK801. J Neurosci. 2008;28:10404-14. 
66. Gray L, McOmish CE, Scarr E, Dean B, Hannan AJ. Sensitivity to MK-801 in phospholipase C-beta1 knockout mice reveals a specific NMDA receptor deficit. Int J Neuropsychopharmacol. 2009;12:917-28.

67. Khella R, Short JL, Malone DT. $\mathrm{CB}_{2}$ receptor agonism reverses MK-801-induced disruptions of prepulse inhibition in mice. Psychopharmacology (Berl). 2014;231:3071-87.

68. Gobira PH, Oliveira AC, Gomes JS, da Silveira VT, Asth L, Bastos JR, et al. Opposing roles of $\mathrm{CB}_{1}$ and $\mathrm{CB}_{2}$ cannabinoid receptors in the stimulant and rewarding effects of cocaine. Br J Pharmacol. 2019;176:1541-51.

69. Xi ZX, Peng XQ, Li X, Song R, Zhang HY, Liu QR, et al. Brain cannabinoid $\mathrm{CB}_{2}$ receptors modulate cocaine's actions in mice. Nat Neurosci. 2011;14:1160-6.

70. Kruk-Slomka M, Banaszkiewicz I, Biala G. The impact of $\mathrm{CB}_{2}$ receptor ligands on the MK-801-induced hyperactivity in mice. Neurotox Res. 2017;31:410-20.

71. García-Gutiérrez MS, Ortega-Álvaro A, Busquets-García A, Pérez-Ortiz JM, Caltana L, Ricatti MJ, et al. Synaptic plasticity alterations associated with memory impairment induced by deletion of $\mathrm{CB}_{2}$ cannabinoid receptors. Neuropharmacology. 2013;73:388-96.

72. Foster DJ, Wilson JM, Remke DH, Mahmood MS, Uddin MJ, Wess J, et al. Antipsychotic-like effects of M4 positive allosteric modulators are mediated by $\mathrm{CB}_{2}$ receptor-dependent inhibition of dopamine release. Neuron. 2016;91:1244-52.

73. Minocci D, Massei J, Martino A, Milianti M, Piz L, Di Bello D, et al. Genetic association between bipolar disorder and 524A>C (Leu133Ile) polymorphism of Cnr2 gene, encoding for $\mathrm{CB}_{2}$ cannabinoid receptor. J Affect Disord. 2011;134:427-30.

74. Atwood $\mathrm{BK}$, Mackie $\mathrm{K} . \mathrm{CB}_{2}$ : a cannabinoid receptor with an identity crisis. $\mathrm{Br} \mathrm{J}$ Pharmacol. 2010;160:467-79.

75. Thomas WG. Immunoprecipitation and phosphorylation of G protein-coupled receptors. Methods Mol Biol. 2009;552:359-71.

76. Stempel AV, Stumpf A, Zhang HY, Özdoğan T, Pannasch U, Theis AK, et al. Cannabinoid type 2 receptors mediate a cell type-specific plasticity in the hippocampus. Neuron. 2016;90:795-809.

77. Li Y, Kim J. Distinct roles of neuronal and microglial $\mathrm{CB}_{2}$ cannabinoid receptors in the mouse hippocampus. Neuroscience. 2017;363:11-25.

78. Navarrete F, Rodríguez-Arias M, Martín-García E, Navarro D, García-Gutiérrez MS, Aguilar MA, et al. Role of $\mathrm{CB}_{2}$ cannabinoid receptors in the rewarding, reinforcing, and physical effects of nicotine. Neuropsychopharmacology. 2013;38:2515-24.

79. Aracil-Fernández A, Trigo JM, García-Gutiérrez MS, Ortega-Álvaro A, Ternianov A, Navarro D, et al. Decreased cocaine motor sensitization and self-administration in mice overexpressing cannabinoid $\mathrm{CB}_{2}$ receptors. Neuropsychopharmacology. 2012;37:1749-63.

80. García $\mathrm{MC}$, Cinquina V, Palomo-Garo C, Rábano A, Fernández-Ruiz J. Identification of $\mathrm{CB}_{2}$ receptors in human nigral neurons that degenerate in Parkinson's disease. Neurosci Lett. 2015;587:1-4.

81. Zhang HY, Gao M, Liu QR, Bi GH, Li X, Yang HJ, et al. Cannabinoid $\mathrm{CB}_{2}$ receptors modulate midbrain dopamine neuronal activity and dopamine-related behavior in mice. Proc Natl Acad Sci U S A. 2014;111:E5007-15.

82. Zhang HY, Gao M, Shen H, Bi GH, Yang HJ, Liu QR, et al. Expression of functional cannabinoid $\mathrm{CB}_{2}$ receptor in VTA dopamine neurons in rats. Addict Biol. 2017;22:752-65.

83. Núñez E, Benito C, Pazos MR, Barbachano A, Fajardo O, González S, et al. Cannabinoid $\mathrm{CB}_{2}$ receptors are expressed by perivascular microglial cells in the human brain: an immunohistochemical study. Synapse. 2004;53:208-13.

84. Stella N. Cannabinoid and cannabinoid-like receptors in microglia, astrocytes, and astrocytomas. Glia. 2010;58:1017-30. 
85. Di Marzo V, Stella N, Zimmer A. Endocannabinoid signalling and the deteriorating brain. Nat Rev Neurosci. 2015;16:30-42.

86. Fernández-Ruiz J, Moro MA, Martínez-Orgado J. Cannabinoids in neurodegenerative disorders and stroke/brain trauma: from preclinical models to clinical applications. Neurotherapeutics. 2015;12:793-806.

87. Komorowska-Müller JA, Schmöle AC. $\mathrm{CB}_{2}$ receptor in microglia: the guardian of self-control. Int J Mol Sci. 2020;22:19.

88. Tanaka M, Sackett S, Zhang Y. Endocannabinoid modulation of microglial phenotypes in neuropathology. Front Neurol. 2020;11:87.

89. Aubry JM. CRF system and mood disorders. J Chem Neuroanat. 2013;54:20-4.

90. Timmermans W, Xiong H, Hoogenraad CC, Krugers HJ. Stress and excitatory synapses: from health to disease. Neuroscience. 2013;248:626-36.

91. Ziegler CG, Mohn C, Lamounier-Zepter V, Rettori V, Bornstein SR, Krug AW, et al. Expression and function of endocannabinoid receptors in the human adrenal cortex. Horm Metab Res. 2010;42:88-92.

92. Bhandari A, Voineskos D, Daskalakis ZJ, Rajji TK, Blumberger DM. A review of impaired neuroplasticity in schizophrenia investigated with non-invasive brain stimulation. Front Psychiatry. 2016;7:45.

93. Vyas S, Rodrigues AJ, Silva JM, Tronche F, Almeida OF, Sousa N, et al. Chronic stress and glucocorticoids: from neuronal plasticity to neurodegeneration. Neural Plast. 2016;2016:6391686.

94. Gerhard DM, Wohleb ES, Duman RS. Emerging treatment mechanisms for depression: focus on glutamate and synaptic plasticity. Drug Discov Today. 2016;21:454-64.

95. Levy MJF, Boulle F, Steinbusch HW, van den Hove DLA, Kenis G, Lanfumey L. Neurotrophic factors and neuroplasticity pathways in the pathophysiology and treatment of depression. Psychopharmacology (Berl). 2018;235:2195-220.

96. Toda T, Gage FH. Review: adult neurogenesis contributes to hippocampal plasticity. Cell Tissue Res. 2018;373:693-709.

97. Howlett AC. Cannabinoid receptor signaling. Handb Exp Pharmacol. 2005:53-79.

98. Cabral GA, Griffin-Thomas L. Emerging role of the cannabinoid receptor $\mathrm{CB}_{2}$ in immune regulation: therapeutic prospects for neuroinflammation. Expert Rev Mol Med. 2009;11:e3.

99. Köfalvi A, Lemos C, Martín-Moreno AM, Pinheiro BS, García-García L, Pozo MA, et al. Stimulation of brain glucose uptake by cannabinoid $\mathrm{CB}_{2}$ receptors and its therapeutic potential in Alzheimer's disease. Neuropharmacology. 2016;110:519-29.

100. Jayant S, Sharma BM, Bansal R, Sharma B. Pharmacological benefits of selective modulation of cannabinoid receptor type $2\left(\mathrm{CB}_{2}\right)$ in experimental Alzheimer's disease. Pharmacol Biochem Behav. 2016;140:39-50.

101. Morgan NH, Stanford IM, Woodhall GL. Functional $\mathrm{CB}_{2}$ type cannabinoid receptors at CNS synapses. Neuropharmacology. 2009;57:356-68.

102. Williams T, Hattingh CJ, Kariuki CM, Tromp SA, van Balkom AJ, Ipser JC, et al. Pharmacotherapy for social anxiety disorder (SAnD). Cochrane Database Syst Rev. 2017;10:CD001206.

103. de Jonge JC, Vinkers $\mathrm{CH}$, Hulshoff Pol HE, Marsman A. GABAergic mechanisms in schizophrenia: linking postmortem and in vivo studies. Front Psychiatry. 2017;8:118.

104. Egerton A, Modinos G, Ferrera D, McGuire P. Neuroimaging studies of GABA in schizophrenia: a systematic review with meta-analysis. Transl Psychiatry. 2017;7:e1147.

105. Sudol K, Mann JJ. Biomarkers of suicide attempt behavior: towards a biological model of risk. Curr Psychiatry Rep. 2017;19:31.

106. Lener MS, Niciu MJ, Ballard ED, Park M, Park LT, Nugent AC, et al. Glutamate and gamma-aminobutyric acid systems in the pathophysiology of major depression and antidepressant response to ketamine. Biol Psychiatry. 2017;81:886-97. 
107. Franklin JM, Carrasco GA. Cannabinoid receptor agonists upregulate and enhance serotonin $2 \mathrm{~A}\left(5-\mathrm{HT}_{2 \mathrm{~A}}\right)$ receptor activity via ERK1/2 signaling. Synapse. 2013;67:145-59.

108. Franklin JM, Vasiljevik T, Prisinzano TE, Carrasco GA. Cannabinoid agonists increase the interaction between beta-arrestin 2 and ERK1/2 and upregulate beta-arrestin 2 and $5-\mathrm{HT}_{2 \mathrm{~A}}$ receptors. Pharmacol Res. 2013;68:46-58.

109. Spiera R, Hummers L, Chung L, Frech TM, Domsic R, Hsu V, et al. Safety and efficacy of lenabasum in a phase II, randomized, placebo-controlled trial in adults with systemic sclerosis. Arthritis Rheumatol. 2020;72:1350-60.

110. Ostenfeld T, Price J, Albanese M, Bullman J, Guillard F, Meyer I, et al. A randomized, controlled study to investigate the analgesic efficacy of single doses of the cannabinoid receptor-2 agonist GW842166, ibuprofen or placebo in patients with acute pain following third molar tooth extraction. Clin J Pain. 2011;27:668-76. 